\title{
Unusual Eruptions Associated with Mycoplasma pneumoniae Respiratory Infections: Review of the Literature
}

\author{
Luisa Terraneo $^{a}$ Sebastiano A.G. Lava ${ }^{a}$ b Pietro Camozzi ${ }^{a}$ Lorenzo Zgraggen $^{a}$ b \\ Giacomo D. Simonetti ${ }^{a}$ Mario G. Bianchetti ${ }^{a}$ Gregorio P. Milani ${ }^{c}$ \\ a Pediatric Department of Southern Switzerland, Bellinzona, and b University Children's Hospital Bern and University \\ of Bern, Bern, Switzerland; 'Foundation IRCCS Ca' Granda, Ospedale Maggiore Policlinico, Pediatric Emergency \\ Department, Milan, Italy
}

\section{Key Words}

Erythema nodosum - Gianotti-Crosti syndrome $\cdot$ Henoch-

Schönlein syndrome - Mucositis · Mycoplasma pneumoniae .

Papular acrodermatitis - Pityriasis lichenoides et

varioliformis acuta Mucha-Habermann . Pityriasis rosea

Gibert · Varicella-like eruption

\begin{abstract}
Background: Maculopapular or urticarial eruptions and erythema multiforme sometimes occur in patients affected with Mycoplasma pneumoniae respiratory infections. Further eruptions have also been reported. Objective: To review the literature addressing $M$. pneumoniae respiratory infection and rather unusual eruptions. Methods: Computer-based search in the US National Library of Medicine database as well as in the search engine Google. Results: We found a possible relationship between $M$. pneumoniae infection and Fuchs' syndrome $(n=37)$, varicella-like eruptions $(n=8)$, Henoch-Schönlein syndrome and further leukocytoclastic vasculitides $(n=21)$ and erythema nodosum $(n=11)$. A temporal relationship was also observed with 2 cases of Gianotti-Crosti syndrome. Finally, there exists reasonable evidence that pityriasis rosea Gibert and pityriasis lichenoides et varioliformis acuta Mucha-Habermann are not associated with
\end{abstract}

(c) 2015 S. Karger AG, Basel

$1018-8665 / 15 / 2312-0152 \$ 39.50 / 0$
Mycoplasma infections. Conclusion: This review implies that M. pneumoniae may cause, in addition to erythematous maculopapular (or urticarial) eruptions and erythema multiforme, Fuchs' syndrome and varicella-like eruptions. Furthermore, there is an intriguing link with leukocytoclastic vasculitides or erythema nodosum that deserves further investigation.

(c) 2015 S. Karger AG, Basel

\section{Introduction}

Skin eruptions sometimes occur in patients affected with Mycoplasma pneumoniae respiratory infections [1]. The most usual eruption is a mild erythematous maculopapular (or urticarial) rash. Targetoid lesions, the hallmark of erythema multiforme, mostly associated with erosions or bullae involving the oral, ocular or anogenital mucosae, are a further common manifestation [2]. Obviously, similar eruptions can also be caused by the antimicrobials prescribed to treat this infection.

Further eruptions have also been observed in patients with $M$. pneumoniae respiratory infections. Since textbooks and reviews only marginally mention these unusual associations, we analyzed the available literature.

\section{KARGER 125\%}

E-Mail karger@karger.com www.karger.com/drm
Mario G. Bianchetti, MD

Pediatric Department of Southern Switzerland

Ospedale San Giovanni

$\mathrm{CH}-6500$ Bellinzona (Switzerland)

E-Mail mario.bianchetti@pediatrician.ch 


\section{Data Assessment}

Between October and December 2014, we performed a computer-based search in the National Library of Medicine database as well as in the search engine Google. Articles published after 1960 were considered, which address a possible link between $M$. pneumoniae respiratory infections and erythema nodosum, Fuchs' syndrome, Gianotti-Crosti syndrome, Henoch-Schönlein syndrome, pityriasis lichenoides et varioliformis acuta Mucha-Habermann, pityriasis rosea Gibert or varicella-like eruptions. For this purpose 'Mycoplasma pneumoniae' and each of the aforementioned conditions (and their synonyms) together with the Boolean operator 'AND' were utilized. Pertinent secondary references were also selected. Reports published in languages other than English, French, German, Italian, Portuguese, or Spanish were not included. Exclusively cases other than erythematous maculopapular and urticarial eruptions or classical erythema multiforme associated with $M$. pneumoniae infections were considered for the analysis. In retained cases, diagnosis of respiratory M. pneumoniae infection was based both on a distinctive clinical presentation and an appropriate laboratory testing [3]. Cases with eruptions possibly due both to Mycoplasma as well as to an already recognized cause (e.g. erythema nodosum with clinical and laboratory findings consistent with both a streptococcal and a M. pneumoniae infection) were excluded [4].

Furthermore, to address their possible quantitative relationship with $M$. pneumoniae infections, case series dealing with $\mathrm{He}$ noch-Schönlein syndrome, erythema nodosum or Gianotti-Crosti syndrome published in English after 1980 were also reviewed.

Using the described strategy, 94 reports were retained for the final analysis [4-97]: 1 in German [23], 1 in Italian [38], 3 in French $[46,51,92], 4$ in Spanish $[20,24,50,81]$ and the remaining 85 in English.

The Fisher test was used to compare dichotomous variables. Statistical significance was assigned at $\mathrm{p}<0.05$.

\section{Results}

The characteristics of 77 patients with Fuchs' syndrome, varicella-like eruption, vasculitis and erythema nodosum associated with $M$. pneumoniae respiratory infection appear in table 1. Fuchs' syndrome (and varicellalike eruption) more frequently affected male subjects than erythema nodosum.

\section{Fuchs' Syndrome (Atypical Erythema Multiforme Major)}

The characteristics of erythema multiforme major, sometimes referred to as Stevens-Johnson syndrome, comprise both targetoid cutaneous eruptions and mucosal erythema, erosions or ulcers involving $\geq 2$ different sites, including the oral region. Erythema multiforme major sometimes presents exclusively with mucosal involvement and is termed atypical erythema multiforme major or Fuchs' syndrome, because this German author
Table 1. Characteristics of patients with Fuchs' syndrome, varicella-like eruption, vasculitis and erythema nodosum associated with M. pneumoniae respiratory infection

\begin{tabular}{lllll}
\hline & $\begin{array}{l}\text { Fuchs' } \\
\text { syndrome }\end{array}$ & $\begin{array}{l}\text { Varicella- } \\
\text { like eruption }\end{array}$ & $\begin{array}{l}\text { Vascu- } \\
\text { litis }\end{array}$ & $\begin{array}{l}\text { Erythema } \\
\text { nodosum }\end{array}$ \\
\hline $\begin{array}{l}\text { Patients, } \mathrm{n} \\
\text { Age, years }\end{array}$ & 37 & 8 & 21 & 11 \\
$\quad \begin{array}{l}\text { Childhood } \\
\text { Adulthood }\end{array}$ & 21 & 5 & 14 & 8 \\
$\begin{array}{l}\text { Gender } \\
\text { Male }\end{array}$ & 16 & 3 & 7 & 3 \\
Female & $32^{\mathrm{a}}$ & $6^{\mathrm{a}}$ & 12 & $2^{\mathrm{b}}$ \\
\hline
\end{tabular}

Number of patients

${ }^{\mathrm{a}} \mathrm{p}<0.01$ vs. patients with erythema nodosum.

$\mathrm{b}$ Information not available in 2 cases.

first reported the condition as 'herpes oris conjunctivae' approximately 150 years ago [98]. Our review disclosed 37 patients affected with Mycoplasma respiratory infection and oral mucositis [5-35]. In addition, ocular involvement was noted in 36, genital in 26 (22 male and 4 female subjects) and anal in 3 cases.

\section{Varicella-Like Eruption}

Eight cases of Mycoplasma infection developed vesicular lesions surrounded by an erythematous halo resembling varicella [36-41]. In these patients, the Tzanck preparation or the virus culture had been used to exclude varicella. Like in patients with atypical erythema multiforme major, lesions of the oral and ocular mucosae were noted in 5 of the 8 cases. Genital lesions were observed uniquely in 2 males.

Henoch-Schönlein Syndrome and Further Vasculitides Leukocytoclastic vasculitides classically present as palpable purpura in the context of Henoch-Schönlein syndrome. Less commonly, they present with targetoid lesions and nonpitting edema in the context of acute hemorrhagic edema of young children, which is considered the infantile variant of Henoch-Schönlein syndrome, or with urticarial plaques in the context of urticarial vasculitis. Our review disclosed 21 cases of leukocytoclastic vasculitides associated with $M$. pneumoniae infection: 18 cases of Henoch-Schönlein syndrome, 1 case of acute hemorrhagic edema and 2 cases of urticarial vasculitis [42-62].

We found 14 case series addressing Henoch-Schönlein syndrome in a total of 2,186 cases published in English- 
language journals between 1984 and 2014 [63-76]. None of the reports included cases associated with $M$. pneumoniae respiratory infection. It is true, however, that none of the articles specifically investigated this association. A systematic review dealing with acute hemorrhagic edema of young children published a few years ago did not find any further association with infections caused by M. pneumoniae [77].

\section{Erythema Nodosum}

Erythema nodosum is characterized by painful erythematous nodules located on the anterior surface of the legs. Our review disclosed 11 erythema nodosum cases associated with $M$. pneumoniae infection $[4,54,58,78-$ 83]. No more than 1 case of erythema nodosum associated with $M$. pneumoniae respiratory infection was noted in 9 case series $[4,79,84-90]$ including a total of 654 erythema nodosum cases not addressing this possible association. However, 4 cases were noted in 3 case series [79, $80,91]$ addressing the mentioned association in a total of 77 erythema nodosum cases.

\section{Other Possible Associations}

Papular acrodermatitis Gianotti-Crosti presents with acral papular eruptions and usually occurs in association with a viral illness, most commonly hepatitis B virus, Epstein-Barr virus or picornaviruses. The association between Gianotti-Crosti syndrome and M. pneumoniae infection was observed in a 4-year-old girl [92] and in a 44-year-old woman [93]. A systematic review of the infections underlying this condition did not disclose any further case of Mycoplasma infection associated with Gianotti-Crosti syndrome [94].

Finally, there exists reasonable evidence that pityriasis rosea Gibert $[95,96]$ and pityriasis lichenoides et varioliformis acuta Mucha-Habermann [97] are not associated with Mycoplasma infections.

\section{Discussion}

There is a recognized causal relationship between $M$. pneumoniae respiratory infections and erythematous maculopapular (or urticarial) eruptions or erythema multiforme major [2]. To our knowledge, this is the first comprehensive review addressing a possible relationship with further skin eruptions. The survey focused on a possible relationship between $M$. pneumoniae infections and erythema nodosum, Fuchs' syndrome, Gianotti-Crosti syndrome, vasculitides such as Henoch-Schönlein syn-
Table 2. Skin lesions that have been associated with M. pneumoniae respiratory infections in the literature

Recognized causal relationship

- Erythematous maculopapular (or urticarial) lesions

- Erythema multiforme (both minor and major form)

- Fuchs' syndrome

- Varicella-like skin eruptions

Not well recognized causal relationship

- Vasculitides (most frequently Henoch-Schönlein syndrome)

- Erythema nodosum

drome, pityriasis rosea Gibert, pityriasis lichenoides et varioliformis acuta Mucha-Habermann and varicellalike eruptions (table 2).

Fuchs' syndrome is a rare form of erythema multiforme major that presents exclusively with mucosal involvement. Likewise, in patients with $M$. pneumoniae infections, varicella-like eruptions are usually associated with a mucous membrane involvement that resembles Fuchs' syndrome. These observations suggest that, like for classical erythema multiforme [2], the correlation between Mycoplasma and Fuchs' syndrome or varicella-like eruptions is causal.

Many cases of Henoch-Schönlein syndrome are preceded by a respiratory illness [99]. In this survey, a relationship between Mycoplasma infection and HenochSchönlein syndrome or other leukocytoclastic vasculitides was documented in no more than 21 cases. Erythema nodosum is traditionally associated with inflammatory bowel disease and with mycobacterial and streptococcal infections [100]. However, most cases are caused by different respiratory infections. Our survey shows a possible relationship between erythema nodosum and M. pneumoniae infection in 11 cases. Many cases of HenochSchönlein syndrome or erythema nodosum are preceded by symptoms and signs consistent with a mycoplasmal infection $[99,100]$. Nonetheless, testing for M. pneumoniae is usually performed neither in Henoch-Schönlein syndrome nor in erythema nodosum. It is therefore concluded that these possible associations deserve further inquiry.

Gianotti-Crosti syndrome is usually associated with viral infections such as hepatitis B or infectious mononucleosis. Since a relationship between Mycoplasma infection and this condition has been documented exclusively in 2 cases, we assume that the association is accidental. A possible relationship between Mycoplasma infections and pityriasis rosea Gibert or pityriasis liche- 
noides et varioliformis acuta Mucha-Habermann has previously been debated, but recent evidence strongly argues against such an association.

The link between $M$. pneumoniae and skin lesions deserves some discussion. M. pneumoniae has sometimes been isolated from targetoid lesions, suggesting that in some instances they represent extrapulmonary spread of the infection [2]. Alternatively, skin lesions result from similarities shared between macromolecules found on Mycoplasma and in host tissue that trigger an immune response [2].

It is traditionally assumed that macrolides, tetracyclines or fluoroquinolones speed recovery in Mycoplasma respiratory infection but do not shorten the course of mucocutaneous manifestations $[2,3]$. Recent data indicate that there is no clear evidence that antibiotic treatment of mycoplasmal pneumonia is effective [101].
The results of our review must be viewed with an understanding of the inherent limitations of the analysis, which is based on the scanty available literature.

In conclusion, this review of the literature implies that M. pneumoniae may cause, in addition to erythematous maculopapular (or urticarial) eruptions and erythema multiforme, Fuchs' syndrome and varicella-like eruptions. Furthermore, the link between this microorganism and vasculitides or erythema nodosum is intriguing and needs further investigations.

\section{Disclosure Statement}

The authors have no conflict of interest to declare.

\section{References}

-1 Ludlam GB, Bridges JB: Association of Stevens-Johnson syndrome with antibody for Mycoplasma pneumoniae. Lancet 1964;283: 958-959.

$\checkmark 2$ Schalock PC, Dinulos JG: Mycoplasma pneumoniae-induced cutaneous disease. Int J Dermatol 2009;48:673-681.

-3 Atkinson TP, Waites KB: Mycoplasma pneumoniae infections in childhood. Pediatr Infect Dis J 2014;33:92-94.

4 Aydın-Teke T, Tanır G, Bayhan GI, Metin O, $\mathrm{Oz}$ N: Erythema nodosum in children: evaluation of 39 patients. Turk J Pediatr 2014;56: 144-149.

5 Sieber OF Jr, John TJ, Fulginiti VA, Overholt EC: Stevens-Johnson syndrome associated with Mycoplasma pneumoniae infection. JAMA 1967;200:79-81.

-6 Alter SJ, Stringer B: Mycoplasma pneumoniae infections associated with severe mucositis. Clin Pediatr (Phila) 1990;29:602-604.

$>7$ Kirke S, Powell FC: Mucosal erosions and a cough. Ir Med J 2003;96:245.

$>8$ Vanfleteren I, Van Gysel D, De Brandt C: Stevens-Johnson syndrome: a diagnostic challenge in the absence of skin lesions. Pediatr Dermatol 2003;20:52-56.

$>9$ Schalock PC, Dinulos JG: Mycoplasma pneumoniae-induced Stevens-Johnson syndrome without skin lesions: fact or fiction? J Am Acad Dermatol 2005;52:312-315.

10 De Ru DH, Sukhai RN: Stevens-Johnson syndrome. Eur J Pediatr 2007;166:1303-1304.

-11 Fearon D, Hesketh EL, Mitchell AE, Grimwood K: Mycoplasma pneumoniae infection complicated by pneumomediastinum and severe mucositis. J Paediatr Child Health 2007; 43:403-405.
12 Latsch K, Girschick HJ, Abele-Horn M: Stevens-Johnson syndrome without skin lesions. J Med Microbiol 2007;56:1696-1699.

-13 Ravin KA, Rappaport LD, Zuckerbraun NS, Wadowsky RM, Wald ER, Michaels MM: $M y$ coplasma pneumoniae and atypical StevensJohnson syndrome: a case series. Pediatrics 2007;119:e1002-e1005.

14 Birch J, Chamlin S, Duerst R, Jacobsohn D: Mycoplasma pneumoniae and atypical Stevens-Johnson syndrome in a hematopoietic stem cell transplant recipient. Pediatr Blood Cancer 2008;50:1278-1279.

15 Figueira-Coelho J, Lourenço S, Pires AC, Mendonça P, Malhado JA: Mycoplasma pneumoniae-associated mucositis with minimal skin manifestations. Am J Clin Dermatol 2008;9:399-403.

16 Hillebrand-Haverkort ME, Budding AE, bij de Vaate LA, van Agtmael MA: Mycoplasma pneumoniae infection with incomplete Stevens-Johnson syndrome. Lancet Infect Dis 2008;8:586-587.

17 Li K, Haber RM: Stevens-Johnson syndrome without skin lesions (Fuchs syndrome): a literature review of adult cases with Mycoplasma cause. Arch Dermatol 2008;148:963-964.

18 Sendi P, Graber P, Lepère F, Schiller P, Zimmerli W: Mycoplasma pneumoniae infection complicated by severe mucocutaneous lesions. Lancet Infect Dis 2008;8:268.

19 Walicka M, Majsterek M, Rakowska A, Słowińska M, Sicińska J, Góralska B, Ptasińska M, Rudnicka L, Marcinowska-Suchowierska E: Mycoplasma pneumoniae-induced pneumonia with Stevens-Johnson syndrome of acute atypical course. Pol Arch Med Wewn 2008;118:449-453.
20 Artés Figueres M, Oltra Benavent M, Fernández Calatayud A, Revert Gomar M: Mucositis grave inducida por Mycoplasma pneumoniae. An Pediatr (Barc) 2009;71:573-574.

21 Choi S-H, Lee Y-M, Rha Y-H: Mycoplasma pneumoniae-induced Stevens-Johnson syndrome without skin manifestations. Korean J Pediatr 2009;52:247-250.

22 Havliza K, Jakob A, Rompel R: Erythema multiforme majus (Fuchs syndrome) associated with Mycoplasma pneumoniae infection in two patients. J Dtsch Dermatol Ges 2009; 7: 445-448.

23 Jakob M, Stuhrmann N, Jordan J, Bootz F, Schröck A: Stomatitis, Cheilitis und Konjunktivitis nach grippalem Infekt. HNO 2009; 57:914-917.

24 Villarroel J, Bustamante MC, Denegri M, Pérez L: Manifestaciones muco-cutáneas de la infección por Mycoplasma pneumoniae: presentación de cuatro casos. Rev Chilena Infectol 2009;26:457-463.

-25 Bressan S, Mion T, Andreola B, Bisogno G, Da Dalt L: Severe Mycoplasma pneumoniae-associated mucositis treated with immunoglobulins. Acta Paediatr 2011;100:e238-e240.

26 McGouran DC, Petterson T, McLaren JM, Wolbinski MP: Mucositis, conjunctivitis but no rash - the 'Atypical Stevens-Johnson syndrome’. Acute Med 2011;10:81-82.

27 Meyer Sauteur PM, Gansser-Kälin U, Lautenschlager S, Goetschel P: Fuchs syndrome associated with Mycoplasma pneumoniae (Stevens-Johnson syndrome without skin lesions). Pediatr Dermatol 2011;28:474-476.

28 Ramasamy A, Patel C, Conlon C: Incomplete Stevens-Johnson syndrome secondary to atypical pneumonia. BMJ Case Rep 2011 DOI: $10.1136 /$ bcr.08.2011.4568. 
29 Schomburg J, Vogel M: A 12-year-old boy 45 Van Bever HP, Van Doorn JW, Demey HE: with severe mucositis: extrapulmonary manifestation of Mycoplasma pneumoniae infection. Klin Padiatr 2012;224:94-95.

30 Hochreiter D, Jackson JM, Shetty AK: Fever, severe mucositis, and conjunctivitis in a 15-year-old male. Clin Pediatr (Phila) 2012; 51:1103-1105.

-31 Trapp LW, Schrantz SJ, Joseph-Griffin MA, Hageman JR, Waskow SE: A 13-year-old boy with pharyngitis, oral ulcers, and dehydration. Mycoplasma pneumoniae-associated mucositis. Pediatr Ann 2013;42:148-150.

-32 Yachoui R, Kolasinski SL, Feinstein DE: $M y$ coplasma pneumoniae with atypical StevensJohnson syndrome: a diagnostic challenge. Case Rep Infect Dis 2013;2013:457161.

- 33 Varghese C, Sharain K, Skalski J, Ramar K: Mycoplasma pneumonia-associated mucositis. BMJ Case Rep 2014 DOI: 10.1136/bcr2014-203795.

34 Šternberský J, Tichý M: Fuchs' syndrome (Stevens-Johnson syndrome without skin involvement) in an adult male - a case report and general characteristics of the sporadically diagnosed disease. Acta Dermatovenerol Croat 2014;22:284-287.

-35 Vujic I, Shroff A, Grzelka M, Posch C, Monshi B, Sanlorenzo M, Ortiz-Urda S, Rappersberger K: Mycoplasma pneumoniae-associated mucositis - case report and systematic review of literature. J Eur Acad Dermatol Venereol 2015;29:595-598.

36 Teisch JA, Shapiro L, Walzer RA: Vesiculopustular eruption with mycoplasma infection. JAMA 1970;211:1694-1697.

37 Lascari AD, Garfunkel JM, Mauro DJ: Varicella-like rash associated with Mycoplasma infection. Am J Dis Child 1974;128:254-255.

38 Ulivelli A, Cocchi P, Paoletti A: Rash varicelliforme associato a infezione da micoplasma. Minerva Pediatr 1976;28:32-35.

39 Chusid MJ, Lachmann BS, Lazerson J: Severe Mycoplasma pneumoniae and vescicular eruption in SC hemoglobinopathy. J Pediatr 1978;93:449-451.

40 Sequeira W, Jones E, Bronson DM: Mycoplasma pneumoniae infection with arthritis and a varicella-like eruption. JAMA 1981;246: 1936-1937.

41 Winnock T, Wang J, Suys E, De Coninck A, Roseeuw D: Vesiculopustular eruption associated with Mycoplasma pneumoniae pneumopathy. Dermatology 1996;192:73-74.

-42 Sussman M, Jones JH, Almeida JD, Lachmann PJ: Deficiency of the second component of complement associated with anaphylactoid purpura and presence of mycoplasma in the serum. Clin Exp Immunol 1973;14: 531-539.

43 Liew SW, Kessel I: Mycoplasmal pneumonia preceding Henoch-Schönlein purpura. Arch Dis Child 1974;49:912-913.

-44 Steare SE, Wiselka MJ, Kurinczuk JJ, Nicholson KG: Mycoplasma pneumoniae infection associated with Henoch-Schönlein purpura. J Infect 1988;16:305-307. Adult respiratory distress syndrome associated with Mycoplasma pneumoniae infection. Eur J Pediatr 1992;151:227-228.

46 Callens A, Machet MC, Vaillant L, PelucioLopes C, Machet L, Barruet K, Lorette G: Purpura rhumatoïde de l'adulte et infection à mycoplasme. Ann Med Interne (Paris) 1993;144: 297-299.

47 Perez C, Mendoza H, Hernandez R, Valcayo A, Guarch R: Leukocytoclastic vasculitis and polyarthritis associated with Mycoplasma pneumoniae infection. Clin Infect Dis 199;25: 154-155.

48 Kaneko K, Fujinaga S, Ohtomo Y, Nagaoka R, Obinata K, Yamashiro Y: Mycoplasma pneumoniae-associated Henoch-Schönlein purpura nephritis. Pediatr Nephrol 1999;13: 1000-1001.

49 Perez C, Montes M: Cutaneous leukocytoclastic vasculitis and encephalitis associated with Mycoplasma pneumoniae infection. Arch Intern Med 2002;162:352-354.

50 Jover F, Cuadrado J M, Ivars J, Merino J: Vasculitis urticariforme e infeccion por $\mathrm{Myco}$ plasma pneumoniae. Enferm Infecc Microbiol Clin 2003;21:215-219.

51 Orlandini V, Dega H, Dubertret L: Vascularite cutanée révélant une infection à $\mathrm{Myco-}$ plasma pneumoniae. Presse Med 2004;33: 1365-1366.

52 Timitilli A, Di Rocco M, Nattero G, Tacchella A, Giacchino R: Unusual manifestations of infections due to Mycoplasma pneumoniae in children. Infez Med 2004;12:113-117.

53 Greco F, Sorge A, Salvo V, Sorge G: Cutaneous vasculitis associated with Mycoplasma pneumoniae infection: case report and literature review. Clin Pediatr (Phila) 2007;46:451-453.

54 Kano Y, Mitsuyama Y, Hirahara K, Shiohara $\mathrm{T}$ : Mycoplasma pneumoniae infection-induced erythema nodosum, anaphylactoid purpura, and acute urticaria in 3 people in a single family. J Am Acad Dermatol 2007;57(2 suppl):S33-S35.

55 Fukuda S, Takahashi T, Kumori K, Takahashi Y, Yasuda K, Kasai T, Yamaguchi S: Idiopathic testicular infarction in a boy initially suspected to have acute epididymo-orchitis associated with mycoplasma infection and $\mathrm{He}-$ noch-Schönlein purpura. J Pediatr Urol 2009; 5:68-71.

56 Lim CSH, Lim SL: Henoch-Schönlein purpura associated with Mycoplasma pneumoniae infection. Cutis 2011;87:273-276.

57 Dua J, Nandagudi A, Sutcliffe N: Mycoplasma pneumoniae infection associated with urticarial vasculitis mimicking adult-onset Still's disease. Rheumatol Int 2012;32:4053-4056.

58 Shimizu M, Hamaguchi Y, Matsushita T, Sakakibara Y, Yachie A: Sequentially appearing erythema nodosum, erythema multiforme and Henoch-Schönlein purpura in a patient with Mycoplasma pneumoniae infection: a case report. J Med Case Rep 2012;6:398.

59 Trčko K, Marko PB, Miljković J: Leukocytoclastic vasculitis induced by Mycoplasma pneumoniae infection. Acta Dermatovenerol Croat 2012;20:119-122.

60 Yiallouros P, Moustaki M, Voutsioti A, Sharifi F, Karpathios T: Association of Mycoplasma pneumoniae infection with HenochSchönlein purpura. Prague Med Rep 2013; 114:177-179.

61 Di Lernia V: Mycoplasma pneumoniae: an aetiological agent of acute haemorrhagic oedema of infancy. Australas J Dermatol 2014; 55:e69-e70.

62 Hu P, Guan Y, Lu L: Henoch-Schönlein purpura triggered by Mycoplasma pneumoniae in a female infant. Kaohsiung J Med Sci 2015;31: 163-164.

63 Saulsbury FT: Henoch-Schönlein purpura. Pediatr Dermatol 1984;1:195-201.

-64 Kumar L, Singh S, Goraya JS, Uppal B, Kakkar S, Walker R, Sehgal S: Henoch-Schönlein purpura: the Chandigarh experience. Indian $\mathrm{Pe}$ diatr 1998;35:19-25.

65 Nussinovitch M, Prais D, Finkelstein Y, Varsano I: Cutaneous manifestations of HenochSchönlein purpura in young children. Pediatr Dermatol 1998; 15:426-428.

66 Saulsbury FT: Henoch-Schönlein purpura in children. Report of 100 patients and review of the literature. Medicine (Baltimore) 1999;78: 395-409.

67 Calviño MC, Llorca J, García-Porrúa C, Fernández-Iglesias JL, Rodriguez-Ledo $\mathrm{P}$, González-Gay MA: Henoch-Schönlein purpura in children from northwestern Spain: a 20 -year epidemiologic and clinical study. Medicine (Baltimore) 2001;80:279-290.

68 Trapani S, Micheli A, Grisolia F, Resti M, Chiappini E, Falcini F, De Martino M: Henoch Schönlein purpura in childhood: epidemiological and clinical analysis of 150 cases over a 5-year period and review of literature. Semin Arthritis Rheum 2005;35:143-153.

69 Cakir M, Orhan F, Mungan I, Sonmez FM, Aslan Y, Kalyoncu M, Erduran E, Gedik Y, Okten A: Henoch-Schönlein purpura in north-eastern Turkey. Ann Trop Paediatr 2006;26:59-65.

70 Nong BR, Huang YF, Chuang CM, Liu CC, Hsieh KS: Fifteen-year experience of children with Henoch-Schönlein purpura in southern Taiwan, 1991-2005. J Microbiol Immunol Infect 2007;40:371-376.

-71 Peru H, Soylemezoglu O, Bakkaloglu SA, Elmas S, Bozkaya D, Elmaci AM, Kara F, Buyan N, Hasanoglu E: Henoch Schönlein purpura in childhood: clinical analysis of 254 cases over a 3-year period. Clin Rheumatol 2008;27: 1087-1092.

72 Anil M, Aksu N, Kara OD, Bal A, Anil AB Yavaşcan $\mathrm{O}$, Un B: Henoch-Schönlein purpura in children from western Turkey: a retrospective analysis of 430 cases. Turk J Pediatr 2009;51:429-436.

73 Hung SP, Yang YH, Lin YT, Wang LC, Lee JH, Chiang BL: Clinical manifestations and outcomes of Henoch-Schönlein purpura: comparison between adults and children. Pediatr Neonatol 2009;50:162-168. 
74 Watson L, Richardson AR, Holt RC, Jones CA, Beresford MW: Henoch Schönlein purpura - a 5-year review and proposed pathway. PLoS One 2012;7:e29512.

-75 Chen O, Zhu XB, Ren P, Wang YB, Sun RP, Wei DE: Henoch Schönlein purpura in children: clinical analysis of 120 cases. Afr Health Sci 2013;13:94-99.

-76 Calvo-Río V, Loricera J, Mata C, Martín L, Ortiz-Sanjuán F, Alvarez L, González-Vela MC, González-Lamuño D, Rueda-Gotor J, Fernández-Llaca H, González-López MA, Armesto S, Peiró E, Arias M, González-Gay MA, Blanco R: Henoch-Schönlein purpura in northern Spain: clinical spectrum of the disease in 417 patients from a single center. Medicine (Baltimore) 2014;93:106-113.

-77 Fiore E, Rizzi M, Simonetti GD, Garzoni L, Bianchetti MG, Bettinelli A: Acute hemorrhagic edema of young children: a concise narrative review. Eur J Pediatr 2011;170: 1507-1511.

78 Teyssandier R, Guidet B, Pinta P, Offenstadt G: Pneumopathie à Mycoplasma pneumoniae avec anémie grave et érythème noueux. Presse Med 1985;14:1613.

79 Cribier B, Caille A, Heid E, Grosshans E: Erythema nodosum and associated diseases. A study of 129 cases. Int J Dermatol 1998;37: 667-672.

-80 Kakourou T, Drosatou P, Psychou F, Aroni K, Nicolaidou P: Erythema nodosum in children: a prospective study. J Am Acad Dermatol 2001;44:17-21.

-81 Rodríguez Blanco MA, Martín Morales JM, Casas Fernández L: Nódulos eritematovioláceos y neumonía. An Esp Pediatr 2002;57: 279-280.
82 Kano Y, Mitsuyama Y, Hirahara K, Shiohara T: Mycoplasma pneumoniae infection-induced erythema nodosum, anaphylactoid purpura, and acute urticaria in 3 people in a single family. J Am Acad Dermatol 2007; 57(suppl):S33-S35.

83 Greco F, Catania R, Pira AL, Saporito M, Scalora L, Aguglia MG, Smilari P, Sorge G: Erythema nodosum and Mycoplasma pneumoniae infections in childhood: further observations in two patients and a literature review. J Clin Med Res 2015;7:274-277.

84 Labbé L, Perel Y, Maleville J, Taïeb A: Erythema nodosum in children: a study of $27 \mathrm{pa}$ tients. Pediatr Dermatol 1996;13:447-450.

85 Hassink RI, Pasquinelli-Egli CE, Jacomella V, Laux-End R, Bianchetti MG: Conditions currently associated with erythema nodosum in Swiss children. Eur J Pediatr 1997;156:851853.

86 García-Porrúa C, González-Gay MA, Vázquez-Caruncho M, López-Lazaro L, Lueiro M, Fernández ML, Alvarez-Ferreira J, Pujol RM: Erythema nodosum: etiologic and predictive factors in a defined population. Arthritis Rheum 2000;43:584-592 (Erratum in: Arthritis Rheum 2000;43:1061)

87 Garty BZ, Poznanski O: Erythema nodosum in Israeli children. Isr Med Assoc J 2000;2: 145-146.

88 Psychos DN, Voulgari PV, Skopouli FN, Drosos AA, Moutsopoulos HM: Erythema nodosum: the underlying conditions. Clin Rheumatol 2000;19:212-216.

89 Tay YK: Erythema nodosum in Singapore. Clin Exp Dermatol 2000;25:377-380.

90 Mert A, Kumbasar H, Ozaras R, Erten S, Tasli L, Tabak F, Ozturk R: Erythema nodosum: an evaluation of 100 cases. Clin Exp Rheumatol 2007;25:563-570.
-91 Cengiz AB, Kara A, Kanra G, Seçmeer G Ceyhan M: Erythema nodosum in childhood: evaluation of ten patients. Turk J Pediatr 2006;48:38-42.

$\$ 92$ Angoulvant N, Grézard P, Wolf F, Truchot F, Marcilly MC, Perrot H: Infection aiguë à Mycoplasma pneumoniae: nouvelle cause de syndrome de Gianotti Crosti. Presse Med 2000;29:1287.

93 Manoharan S, Muir J, Williamson R: Gianotti-Crosti syndrome in an adult following recent Mycoplasma pneumoniae infection. Australas J Dermatol 2005;46:106-109.

94 Brandt O, Abeck D, Gianotti R, Burgdorf W: Gianotti-Crosti syndrome. J Am Acad Dermatol 2006;54:136-145.

95 Chuh AA, Chan HH: Prospective case-control study of chlamydia, legionella and mycoplasma infections in patients with pityriasis rosea. Eur J Dermatol 2002;12:170-173.

$\$ 96$ Chuh A, Chan H, Zawar V: Pityriasis rosea - evidence for and against an infectious aetiology. Epidemiol Infect 2004;132:381390.

-97 Fernandes NF, Rozdeba PJ, Schwartz RA, Kihiczak G, Lambert WC: Pityriasis lichenoides et varioliformis acuta: a disease spectrum. Int J Dermatol 2010;49:257-261.

98 Fuchs E: Herpes oris conjunctivae. Klin Monbl Augenheilkd 1876;14:333-351.

-99 Ting TV: Diagnosis and management of cutaneous vasculitis in children. Pediatr Clin North Am 2014;61:321-346.

100 Requena L, Yus ES: Erythema nodosum. Dermatol Clin 2008;26:425-438.

101 Biondi E, McCulloh R, Alverson B, Klein A, Dixon A: Treatment of mycoplasma pneumonia: a systematic review. Pediatrics 2014; 133:1081-1090. 